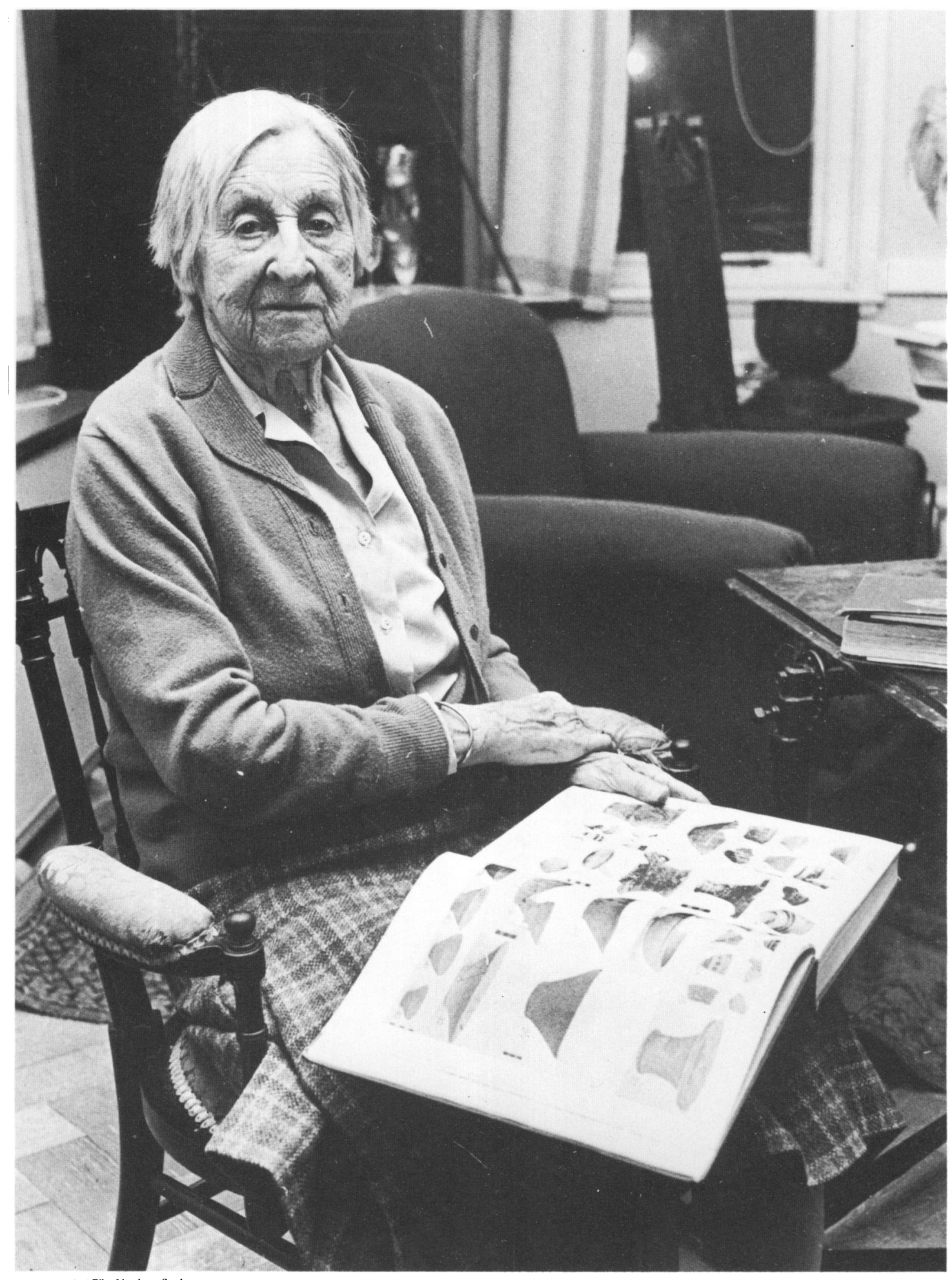

Photograph: 'The Northem Scot' 


\section{SYLVIA BENTON}

Sylvia Benton was born on 18 August i 887 at Lahore, where her father was a judge of the Chief Court of India; her mother was a Rose of Sheriffston, Moray. She was educated at St Margaret's, Polmont, and Wimbledon High School. She went up to Girton in I 907 and took finals in classics in 1910 ; she represented Cambridge women and Girton College in hockey and tennis. She then started teaching in schools, took the Cambridge Teachers' Certificate in I 912, and was a schoolmistress in Oldham, Reading, and Clapham for fifteen years until her circumstances allowed her to devote herself full time to archaeology.

She had started travelling on foot in Greece in I926; but she was first admitted Student at the School in the Session 1927-8, when she assisted Heurtley in his excavations in Chalcidice. In I 928-9 she was not readmitted; she later claimed that this was because she had, as her own 'diaries' show, disobeyed the Director's order not to climb Taygetus alone-which she in fact did by cutting steps in the snow with her stick. But this did not prevent her from assisting at Heurtley's dig at Saratse in 1929. In these years she travelled extensively in Greece with gifted archaeologists like Heurtley, Ralegh Radford, and Pendlebury, and the mineralogist Oliver Davies. Her diaries of these journeys show her gradually developing into the fearless, hardbitten traveller whom we remember.

With the support of Professor J. L. Myres she was accepted by Lady Margaret Hall and started in January I 929 to read for the Diploma in Classical Archaeology, which she obtained in $193^{\circ}$. She was duly readmitted to the School from the 1929-30 Session onward. She again assisted Heurtley in Macedonia, at Servia in 1930, and Armenochori in 193 I. This training with Heurtley, combined with her journeys of prospection in Macedonia, the Epirus and Thessaly, Central Greece, and elsewhere, made her a proficient and keen-eyed prehistorian. She went on to take an Oxford B.Litt. with a dissertation on the Barony of Odysseus ( 1934 ); and she was elected FSA in 1937. She was later to tutor several students for the Oxford diploma.

In I 928-30 she excavated the Sculptor's Cave at Covesea on the Moray Firth, bringing out pieces of its clay floor and sieving them in the gale at the cave mouth. Besides interesting relics of Roman times in two phases she found Bronze Age occupation with metal objects and bone implements for which she discovered the closest parallels in Central Europe. Her conclusion that the occupants had immigrated from there was a revolutionary theory when she propounded it to the Scottish Society of Antiquaries in January I93 I. 'They were very kind to me in Edinburgh when I produced my paper [she noted], but only Professor Childe really liked my invasion theory, and he set to work to support it. . . ' This he did successfully; and it followed that the comparable bone tools in Swiss museums must be down-dated from the Neolithic. Thirty years later the 'Covesea phase' had been recognized as 'the most important horizon of the Scottish Late Bronze Age'. In I978-9 the area of the cave floor which Sylvia had deliberately left untouched was excavated by Ian A. G. Shepherd who has kindly sent a personal comment on her work: 'The Late Bronze Age material and conclusions that she drew have stood up remarkably well, with certain, inevitable, modifications', and 'The sieving of every bucket/spadeful of deposit was remarkable for its time in Scotland, as was the amount of horizontal control she exercised through her grid.'

In October 1927 she had visited Ithaca alone, and in $B S A 29$ she published a short article on earlier finds from there. Soon after this she carried out an extensive and archaeologically productive exploration ( $B S A 3^{2}$ ) of the islands, little archipelago, and mainland coasts from 
Lefkas to Zakynthos, extended in the second of 'two pleasant summers' to Kythera where she discovered the site later excavated by Huxley and Coldstream (their book is dedicated to her). Consequently, she was an immediate choice for Heurtley's team which under Rennell of Rodd's sponsorship excavated in Ithaca in $193^{\circ-2}$ and r 934 . She did dig a Neolithic cave at Astakos in 1932 (BSA 42) and (with Hilda Lorimer) a couple of unrewarding sites on Zakynthos in I934; but she had lost her heart to Ithaca and from that time on it was the focus of her intense and enduring affection.

In I930 she was assigned a site (in fact a collapsed ancient cave) on Polis Bay, whose floor had been submerged by the rise in sea level (BSA 35 and 39). Working in a bathing dress and largely under water (with assistance from Hammond) she started to clear and sift the deposit. But as Ralegh Radford has emphasized in a letter, she quickly recognized that it was a stratified site and must be drained. With assistance from George Tait and Radford this was successfully achieved with pump and dams in 1932 . Within the stratification thus established she discovered the remains of prehistoric occupation and of a cult that might have started in Mycenaean times. The most exciting finds were substantial remains of twelve great cast bronze Geometric tripods, some dedications to the Nymphs, and a Hellenistic ex-voto to Odysseus. Added to one previously found by Louizos, the tripods linked the cave to that in which Odysseus stored the thirteen tripods that Homer has him bring home from Scheria. In a long and important article ( $B S A$ 35) Sylvia revised Furtwängler's classification of tripods; her mature view was that one of her tripods might date to the ninth century but the others all fall between 776 and about 700 BC. In the continuing study of Greek hero cults the Polis cave retains its unique interest. During I 93 I and I 934 Sylvia also assisted Heurtley in his excavations at Aetos on the waist of the island.

After this Sylvia was largely concerned with working up her finds for publication; she also extended her travels, museum studies, and research interests in a number of different directions. But Heurtley's departure from the School had left a blank. In I 937 Sylvia started excavations on her own account in the north of Ithaca, that at Tris Langades above Polis Bay (completed in I938) revealing the one Mycenaean settlement discovered on the island (S. B. and Helen Waterhouse in $B S A$ 68). But chance finds drew her attention back to Aetos, where she resumed excavation in $193^{8}$. It turned out that the very rich sanctuary deposit of later Geometric and Archaic times there (Heurtley and Robertson in BSA 43) had only been half cleared. Her new finds left Sylvia with years of work at the Vathy Museum in front of her $\left(B S A 4^{8}\right)$.

Catching the last boat from the eastern Mediterranean (the Cairo City) in late August 1939 Sylvia was back in England for the war. She worked for naval hydrography in 1940, collaborating in a 'Gazetteer of Greece' and a 'Glossary of Modern Greek', and then in Postal and Telegraph Censorship (Uncommon Languages Dept.) by day, with fire-fighting at night, until her bedroom was destroyed and she herself badly injured in the bombing of London in I945.

By spring 1947 she was back in Ithaca, where she resumed work on her excavation material and reconstituting the Vathy Museum. By I953 she was free to spend five weeks studying prehistoric material in the Chaeronea Museum. But devastating earthquakes then struck the Ionian Islands and she hastened to undertake rescue work in Vathy, where the Museum was in ruins, and in a lesser degree in the Stavros Museum. This led to further long spells of residence in Ithaca which continued with intervals until I974; at the end she needed to be escorted in Greece (a role in which her close friends such as Jock Anderson and Helen Brock played their parts); but she delighted in giving her 'keeper' the slip on occasions. 
About 1957 Sylvia turned her attention to monsters, winds, and, above all, birds in Greek art. She had several articles published (principally in $7 H S$ ), but it was a disappointment to her that the book on birds, on which she laboured for well over a dozen years with failing eyesight, could not be brought to publication.

She moved from Oxford to her beloved Moray in 1970 and so was less accessible to her friends. But she was for a time Hon. Curator of the Elgin Museum, and she achieved contentment and finally serenity in her later years. From April I 984 she was being cared for by her great-niece, Mrs Elizabeth Neill, at Kincraig. She was ever a 'good trencher-woman'meat and drink agreed with her; and she was taking her daily walk until the end. Though deaf she could recall the old days and was telling amusing stories of them when visited two months before her death. After a fall she died in hospital in Inverness on I 2 September I 985 . A shame she didn't make her century! For she was a 'bonny fechter'.

Sylvia was extraordinarily agile. She loved strenuous exercise and in her sixties was as sharp as ever at the net on the school tennis court. She had a flair for doing unconventional things, not confined to a certain bizarreness in dress (when she found herself precariously poised on a cliff near Perachora she signalled to some passing boatmen, who rowed away in terror declaring that they had seen the Antichrist). After dancing on board HMS Resolution at Argostoli on the occasion of the Mediterranean Fleet's summer cruise she persuaded the commander to 'swing her out' so that she could inspect a cave in a cliff. The hairpin bend (never precisely fixed) on the road in Ithaca that used to be known as 'Benton's Push' was, she insisted, mythical; but her early 'diaries' do show her adopting so aggressive a stance against an assailant near Delphi that he fell backwards into a torrent bed. In her early nineties she fended off a nocturnal attacker in her bedroom at Lossiemouth and was in hospital for a while recovering from her injuries. Soon after being discharged she visited the new excavation at Covesea, climbing down 90 feet of scaffolding and returning up it so fast that the rope-holders could not keep pace in drawing in the slack.

About 1930 she broke her collar-bone in a taxi accident in Paris on her way to an interview with Salomon Reinach. To Catherine Cole, while the fracture was still knitting, she gave the impression that she had fainted on his hearthrug or thereabouts. But such weakness on her part was not to be admitted to young male students, and the version she told in the mid thirties had her proffering the two ends ('Mais regardez, Monsieur') and the great French savant insisting that she had not broken it because if she had done so she would have fainted. In 1937, having left her passport behind in the Rome School, she had her Peloponnesian railway card stamped by the French authorities at the Paris exhibition in sight of Picasso's Guernica. Arriving in Ithaca on a Greek minesweeper after the I 953 earthquake she is credibly stated to have dived from the deck in order to be the first person ashore.

In her spiritual make-up one might perhaps sense Sir Patrick Spens, the chieftains of the '45, the British raj, and Pindar's nymph Cyrene (though Sylvia of course remained invincible). People could find her too impatient and at times even exasperating; but to some she was very dear. She had a fine repertory of anecdotes, which-even when least believable-fitted with the personality of the subject: Hilda Lorimer, for instance, after the usual explosion, tottering down the stairs of the hostel in her kimono, pursued by the cap of the geyser and muttering 'It oughtn't to be allowed'.

Her style of writing was direct and pithy. She complained of an editor of $B S A$ cutting out her jokes. But memorable phrases won through: the malingering workman at Astakos who 'attributed his alleged fever to the miasma of the Neolithic dead', the insufficiently cremated Middle Helladic burials on Lefkas which she referred to as Dörpfeld's 'toasted corpses', or 
her comment (in a $\mathcal{J} H S$ review) on a dubious Minoan seal showing three court ladies standing with sweeps to propel a canoe- 'One wave and those fine ladies will be in the drink'.

Sylvia's scholarly output was wide-ranging and substantial: a dozen articles (several of them massive) in $B S A$, six in $\mathcal{J} H S$, others in Man, PBSR, PSSA, PPS, Archaeology, Antiquity, GJ, CQ, the Banti Festschrift, and reviews in $\mathcal{J} H S$, Antiquity, and $A \mathcal{J}$. In discussion she could be erratic and jump hastily to conclusions, and her presentation was sometimes proleptic; consequently her scholarly contributions were apt to be underrated. In fact she disdained all contrived hypotheses, and the serious contentions that she advanced show cool judgement and have generally been proved right-such were the Bronze Age immigration from the Rhine lands on the east coast of Scotland, her characterization of the Mycenaean pottery of Ithaca and its neighbours, the absence of a palace for Odysseus at Pelikata, the supposed Protogeometric burial cairns of Aetos, the classification of Iron Age tripods and dating of Cretan shields, the significance of early Corinthian pottery in Ithaca and 'Blakeway wares' in Southern Italy, and prehistoric interconnections between the Balkans, central Greece, and the West. In archaeology for half a century she saw what she wanted to do and did it well; not least, she enjoyed doing it.

J. M. C. 